\title{
Forms and Functions of Nakedness in Middle English Romances
}

\author{
Julia Josfeld
}

\section{Introduction}

We live in a highly sexualised culture. Images of naked bodies are used to sell us everything, from clothing to beer, and the phrase "sex sells" has become so commonplace that it is rarely ever challenged. Especially in popular culture, in movies, magazines, music videos, and so on, erotic imagery is normal, in some contexts even expected. But has it always been this way?

During the High and Late Middle Ages, one very popular genre of literature was the romance: stories of valiant knights, virtuous kings, mysterious fairy folk, and beautiful ladies. Many of these stories have as one of their central elements the pursuit of love or conflicts caused by sexual desire. Over the centuries, the importance of this aspect seems to have grown in the perception of readers, to the point where in modern English the name of the genre has become a word we associate exclusively with love, wooing, and relationships. Judging by this, it might be tempting to assume that an equivalent to our sexualised popular culture might have flourished in these particular texts. However, there are some scholars who strongly urge caution when talking about eroticism and sexualised bodies in the Middle Ages.

In her article "The Body of Christ in the Later Middle Ages," Caroline Walker Bynum set out to refute an argument made by Leo Steinberg a few years earlier regarding the depiction of Christ in the late Middle Ages and early Renaissance. 
Steinberg had brought together a number of paintings which, according to him, put a clear focus on the penis of Christ to emphasise his sexuality. ${ }^{1}$ While Bynum does not contradict Steinberg's findings regarding the images, she draws a different conclusion: the depiction of and focus on Jesus' genitals would not necessarily have been perceived as sexual in the late Middle Ages. She finds that

[t]wentieth-century readers and viewers tend to eroticize the body and to define themselves by the nature of their sexuality. But did medieval viewers? For several reasons, I think we should be cautious about assuming they did. (Bynum 406)

Bynum goes on to argue that the focus which later medieval theology and especially Mysticism placed on Christ's body only rarely, if at all, concerned his existence as a sexual man. Rather, his physicality was associated with his "humanation" (403), his becoming human so he could suffer and die on the cross, thus leading humankind to salvation (407-08).

While Bynum's article makes some sweeping statements questioning the connection of the body and sexuality in medieval minds (like the one mentioned above), she only elaborates in detail on the body of Christ and whether it was sexualised in the fifteenth and sixteenth centuries. Nevertheless, her conclusions have been applied more broadly, causing academics to challenge ideas about sexuality and the erotic in medieval depictions of naked bodies (see e.g. Schultz 92, reiterated in Hopkins 60). In this paper, I will continue along this line of questioning: is the instinct to associate naked bodies with eroticism and sex justified in the context of Middle English romances? And what does it even mean to be "naked" in the Middle Ages?

To answer these questions, I will first try to shed some light on the scholarly debate concerning nakedness in the Middle Ages. As one might expect, a topic that borders so strongly on the taboo has not yet been studied to a great extent, although in recent decades, as more scholars have turned towards the fields of sexuality and bodies in literature, some interesting theories have been put forth. Despite the relatively small amount of available research, establishing an understanding of the medieval conceptions of nakedness is crucial: literary devices exist in context, and to decipher the meaning they held for their contemporary audience, one must understand that audience's reality.

The specific texts which will be analysed in this paper are a collection of relatively well-known thirteenth- and fourteenth-century romances, which contain a wide variety of scenes presenting different forms of nakedness. ${ }^{2}$ On a surface level, many of these scenes seem to entail a certain erotic frisson, or at least potential for such, but this is not always the case. By examining the naked bodies

\footnotetext{
1 The arguments of his book, The Sexuality of Christ in Renaissance Art and in Modern Oblivion are summarised in Bynum 403.

2 The chosen romances will be introduced in greater detail in the first subsection of "Nakedness in Middle English Romances."
} 
present in these romances in their textual and historical context, I will endeavour to determine in how far nakedness was used as a signal for eroticism and sexual tension, and if, as a literary device, it could serve any other functions.

\section{Being Naked in the Middle Ages}

The Meaning of "naked"

The first question that needs to be asked when talking about nakedness in a medieval context may also be the most fundamental one: what did it mean to be described as "naked" in the Middle Ages? In 1992, Robert Jütte attempted a semiotics of the naked body throughout time. He pointed out that nakedness could have two modes: being with or without clothing (112-15). Nakedness without clothing is what we in modern times would still understand as being naked, but nakedness with clothing might not be as familiar.

Examining medieval plays, German ethnologist Hans Peter Duerr has pointed out that characters were often explicitly described as naked while the actors portraying them were in fact dressed in flesh-coloured suits or white chemises (292). He finds that sources draw a clear distinction between someone being "naked," meaning poorly or inadequately dressed, and being "fully naked"; a sentiment that is reiterated for example by Silke Winst (347). Nakedness is generally regarded as a social construct rather than an absolute value (see e.g. Bießenecker 12), and it would appear that the medieval conception of nakedness expanded beyond our modern understanding to include any form of socially insufficient clothing.

A literary example of this expanded concept can be found in the first few lines of the late thirteenth-century romance Havelok. ${ }^{3}$ We read about the eponymous hero: "The tale is of Havelok i-maked: / Wil he was litel he yede ful naked" (5-6). While Shepherd gives a translation here of "completely naked" and adds a note interpreting this statement to mean "in youth he was destitute," other editors have glossed the word "naked" as "poorly dressed" (54). Later in the same poem, the word is used to describe a state of complete undress (2123) as well as to imply poor clothing, but clothing nonetheless (853). ${ }^{4}$ Similar evidence can be found in other romances of the time, suggesting that the medieval concept of "nakedness" includes more than just bodies entirely devoid of clothing. Therefore, to properly examine the function of nakedness and its erotic qualities in Middle English literature, the medieval conception of nakedness should be taken into account, and instances of inadequate clothing must be considered alongside scenes of explicit nudity.

\footnotetext{
3 All quotations refer to Shepherd's edition of Havelok.

${ }^{4}$ For a more detailed discussion of nakedness in Havelok, see the subsections on "Poverty" and "Identity."
} 
The Historical Debate over Nakedness

Before looking at the actual text, it is necessary to examine medieval attitudes towards nakedness. What might have gone through the minds of medieval readers when they were reading about a man running naked through the woods? Or a noble lady lying in bed with another man, both of them only wearing nightclothes, if any clothes at all? Would they have regarded such displays as extraordinary, worthy of particular note, maybe even subversive, or would they have shrugged them off as not too far removed from ordinary, everyday occurrences? When trying to analyse the functions of nakedness in medieval texts, we must first attempt to answer these questions. If, as some scholars have argued, public nakedness was indeed commonplace in the thirteenth and fourteenth centuries, ascribing erotic meaning to the naked bodies of Middle English romances would distort their narrative function. On the other hand, if nakedness was generally completely unacceptable, scenes involving even just implied nakedness might have inherently held strong meaning, erotic or otherwise, for medieval readers. To answer this question, we need to take into account the scholarly debate on the topic of nakedness and shame that has taken place over the past decades.

Two of the most important and influential voices in this debate are those of sociologist Norbert Elias and ethnologist Hans Peter Duerr. In 1939, Elias published his seminal, multi-volume work Über den Prozess der Zivilisation, which was reprinted and started to gain wide recognition in 1969. In these books, Elias puts forth the theory that society in the Middle Ages was less disciplined, less restrictive, in short: less civilised than it is today. A shift occurred in the Renaissance, when people in the West started to impose stricter rules and behavioural norms on themselves and on their communities as a whole, thus moving us gradually towards what we recognise as our modern society (Elias 79). Hans Peter Duerr, meanwhile, devoted his most celebrated work to disproving Elias's theory in detail and in its entirety. The aptly-named Der Mythos vom Zivilisationsprozess was published in five volumes, starting in 1988 with the book Nacktheit und Scham. The conflict between these two scholars and their ideas has sparked enough controversy that it is still referred to and discussed as the "Elias-Duerr-Kontroverse." 5 However, for the purposes of this paper, the general merits and failings of Elias's and Duerr's claims regarding the process of civilisation will not be discussed in detail. Rather, I will use those of their arguments that touch on nakedness in the Middle Ages to gain insight into the state of scholarly thinking on this topic.

According to Norbert Elias, nakedness, even in public, was accepted in the Middle Ages and not regarded as shameful or embarrassing. Bodily functions were only moved into private and concealed spaces towards the beginning of the Renaissance (Elias 49), and being naked in front of members of the opposite sex, e.g. in bed or while bathing, was not an extraordinary occurrence (294). Elias's

\footnotetext{
5 A detailed discussion can be found in Hinz 349-91.
} 
assumptions are based on conduct books from the thirteenth century onwards, as well as medieval and early modern literary texts, eye-witness accounts, and illustrations, covering a wide range of pre-modern Western European societies. Hans Peter Duerr, on the other hand, has taken issue with Elias's interpretation of most, if not all, of these sources, as well as with his colleague's broader conclusions. According to Duerr, humans have always regarded nakedness as inherently shameful, and this can be deduced from the sources if one knows where to look (12). He does not find a significant shift in attitudes towards the naked body between the Middle Ages and today, claiming that no medieval person would have willingly exposed their body in front of strangers, unless they were prostitutes or deviated in some other way from the societal norm (32).

Throughout the years, most scholars have taken a view that falls somewhere between these two positions, arguing sometimes for more, sometimes for less permissiveness. But to better understand the implications of this controversy, I will look at two examples of hotly-debated aspects of historical medieval nakedness. Beyond the general assertions made by Elias, Duerr, and their commentators, several concrete situations in which one would expect to find-or not to find-nakedness are often highlighted and examined in detail, trying to gauge medieval attitudes towards the naked body. First among these are the bed and the bath.

Bed, Bath, and Beyond: Nakedness in Context

The question of whether medieval people slept naked has been debated for several decades. Elias asserts that sleeping in the nude was the norm during the Middle Ages, and that specialised clothing to be worn at night was not developed until the Renaissance (224). Going one step further, he claims that it was commonplace for people to share a bed, even if they did not know each other, and sometimes even if they were of different gender (240). Even before Elias, other cultural historians have made this claim, citing for instance illustrations of seemingly naked men and women lying in the same bed, but - as is to be expected-Duerr takes issue with this view.

According to Duerr, it would have been highly unlikely to find a medieval man and woman sleeping in the same bed unless they were husband and wife, and it would have been even stranger to find them naked (177). Looking at the same sources as Elias, he interprets them entirely differently. Where men and women are depicted sharing a bed, Duerr reads the image as a romantic or even erotic scene, if not a straightforward medieval representation of a brothel (179). Similarly, Elias uses a medieval text in which a lord allows an honoured guest to share his wife's bed, to back up his claim that strangers sleeping together was commonplace (230). Duerr, on the other hand, raises the objection that the existence of this report showcases how exceptional such an offer would have been, since it was only made to a very special guest of the house (183). Indeed, two unmarried 
people sleeping in one bed could have harmed their reputation irreparably, even if no sexual intercourse occurred (183).

In addition to refuting Elias's arguments, Duerr also adds some sources of his own, to strengthen his position. For example, he quotes ordinances from guest houses along a popular pilgrimage route that forbid guests to sleep in their normal clothing - a requirement that would only be necessary if guests did habitually go to bed fully dressed (Duerr 181). Other evidence Duerr produces stems from religious houses, which appear to have enforced strict policies of single occupancy and all-night lighting to prevent untoward goings-on (191-92).

However, just as Duerr took issue with Elias's conclusions, other scholars have criticised Duerr's sources for being too selective. While it is quite likely that religious orders and the institutions they ran, such as boarding houses and hospitals, adhered to a strict moral code, this does not necessarily reflect the general attitudes of society (Classen, Sexuality 76). Additionally, some scholars think that night shirts, which survive from the late Middle Ages or are at least credibly attested, were rare items that would have been a luxury of the upper classes, not a usual household item for the majority of medieval society (Classen, "Naked Men" 145). Most scholars, including Robert Jütte, once again find the truth somewhere between the two extreme positions. They consider it most likely that the decision whether to sleep in the nude or in some form of night-dress, be that a shirt, breeches, or a full-on nightgown, would have depended on the situation and on individual preference (Jütte 120).

A similar divide can be found regarding the question whether it would have been normal for medieval people, especially people of different genders, to bathe together or in front of each other, and if so, whether they would have been naked doing it. Here too, positions are extremely divided, with Elias giving sources that seem to demonstrate the commonplace nature of naked, mixed-gender bathing (319), and Duerr discrediting his reading of those sources and claiming that nakedness in the bath would have been highly problematic (24). Sources include depictions that clearly show men and women sharing a bathtub while very lightly dressed, if they are dressed at all. These images are taken by Elias as proof of mixed public baths (319), whereas Duerr recognises them as scenes from brothels or other disreputable houses (50). Furthermore, Duerr argues that even if men and women had bathed in each other's presence, they would not have been naked. Rather, they would have worn a chemise or braies (44), and many medieval bathtubs would have been covered with a cloth or a wooden partial lid to preserve the heat. In the absence of such covers, flower petals or leaves might have been strewn on the water to preserve the bathing person's decency (Duerr 25-26). The question of nakedness in the bath has not been as hotly debated as that of nakedness in bed, but where scholarly discourse exists, it predictably tries to find a middle ground between the two extreme positions, stating that whether or not bathing 
naked in the company of others was acceptable depended wholly on the circumstances (Classen, “Naked Men” 159).

One issue of relevance for the interpretation of Middle English romances is bathing in front of servants. In Duerr's understanding, discrepancies in social class did not mitigate the shame of revealing one's naked body in front of another person (243). The story of a noblewoman who gleefully exposes her private parts in front of a male servant, used by Elias once again to reinforce his thesis (77), is taken by Duerr to represent an anomaly, which is why a report of this episode survives at all (243). Robert Jütte takes the moderate position that bathing naked in front of servants, or, similarly, a lady being washed by a bather, would not have been perceived as embarrassing or transgressive, as long as everyone adhered to their social roles. Uncomfortable moments would only arise if a person broke the conventions by insisting on being perceived as an individual rather than filling a specific role. He gives the example of a lady asking a bather to tell her whether her breasts were more beautiful than those of other ladies, thus making her more than just another naked body among the many the bather would deal with on a daily basis, and causing great embarrassment to the man (Jütte 118).

To sum up, there seems to be no clear consensus among scholars on how the average medieval mind would have viewed a naked body, whether nakedness was pervasive and accepted or taboo and transgressive. If, as Elias and his followers suggest, being naked in front of strangers was a normal part of life, scenes involving naked characters in medieval literature might not necessarily have incited thoughts of eroticism and sexuality in their audience. If, on the other hand, as Duerr surmises, nakedness was always perceived as embarrassing and shameful, basically every scene involving characters explicitly or implicitly in a state of undress would hold specific, probably sexual significance. But because the truth most likely lies somewhere in between these two extremes, each mention of nakedness in Middle English romance, and indeed each scene where we expect nakedness but do not find it, needs to be examined and evaluated individually. By determining the specific forms that nakedness takes and the narrative functions it serves, we may gain a better understanding of whether or not the naked body was generally used as a symbol of eroticism and sexuality in this particular medieval genre.

\section{Nakedness in Middle English Romances}

The Romances

The texts here examined date from the thirteenth and fourteenth centuries. Mainly, I will be looking at four romances: Havelok, Ywain and Gawain, Sir Orfeo, and Sir Launfal. While it is difficult to tell how widely texts were received in the Middle 
Ages, these four texts hold a certain popularity among scholars and critics today. Although they represent different thematic sub-genres of romance, ${ }^{6}$ such as the Breton Lai (Orfeo and Launfal) or the Matter of England (Havelok), there are some surprising parallels in motifs, plot elements, and characterisations between them, and they all contain scenes that allow interesting insights into the forms and functions of nakedness.

In addition to these main texts, I will cover some material from the very wellknown Chaucerian romance Troilus and Criseyde, as well as the less famous tales Sir Gawain and the Carle of Carlisle, and The Avowyng of Arthur. The latter two texts also mark the latest romances in this study, since Carlisle is presumed to have been composed in the last quarter of the fourteenth or the first quarter of the fifteenth century, and The Avowyng is traditionally dated to around $1400 .^{7}$ Of course there are many more romances that involve naked characters at some point or other, but this selection already covers a wide range of different contexts in which nakedness occurs, and lays out a broad variety of forms and functions of the same.

Hot, Erotic, and Exotic: The Naked Lady in the Woods

One of the more striking examples of nudity in an erotic context to be found in Middle English romances is the first meeting between the fairy princess Tryamour and the Arthurian knight Sir Launfal in the romance of the same name. ${ }^{8}$ Launfal, who has left King Arthur's court after being snubbed by Queen Guinevere, has fallen destitute, and, one summer morning, tries to escape his misery by riding away from the town where he resides into a nearby wood. There he is met by two beautiful ladies who invite the knight to meet their mistress, who has long admired him from afar. Launfal follows the ladies to a clearing where he finds Tryamour, lying on a luxurious bed inside a splendid pavilion. The poet describes the lady as follows:

For hete her clothes down sche dede

Almest to her gerdylstede;

Than lay sche uncovert.

Sche was as whyt a lylye in May,

Or snow that sneweth yn wynterys day;

He seygh never non so pert. (289-94)

Upon seeing that the object of her desire has arrived, Tryamour proposes to Launfal that she will give him unending riches and become his secret lover, as

\footnotetext{
${ }^{6} \mathrm{I}$ use this term loosely: the hotly debated definition of romance and its subgenres is beyond the scope of this paper.

${ }^{7}$ For details of the dating, surviving manuscripts, and general state of scholarship on all of these texts, see their respective introductions in the listed editions.

8 All quotations refer to Shepherd's edition of Sir Launfal.
} 
long as he keeps her existence a secret. Launfal agrees and the two have dinner and spend the night together. The erotic nature of the initial encounter cannot be denied — not least because it is followed by declarations of love and, ultimately, by sex: "For play lytyll they sclepte that nyght, / Tyll on morn hyt was daylight" (349-50). What is not entirely obvious, however, is which elements of the scene would have made it appear erotic to a medieval audience.

In her article on Christ's body and sexuality, Bynum writes that female breasts were not necessarily sexualised in the Middle Ages. Rather, they were associated with nurturing and motherhood. To support her claim, she points out the many depictions of Jesus' mother Mary with exposed breasts, feeding her son (Bynum 407). Of course, Mary's status as a (if not the) virgin and the mother of Christ might have made it more acceptable to depict her in a fashion which would have been unsuitable for medieval noblewomen, but even so, these depictions demonstrate that naked breasts did not immediately imply eroticism. Looking at the halfnaked Tryamour in this light, we are forced to reconsider her presentation, which can so easily be construed as pure erotic wish-fulfilment (Kelly 250).

Despite Bynum's argument, readers are unlikely to find many half-naked ladies displaying themselves semi-publicly for male view in Middle English literature, so why is Tryamour allowed such a transgression? One clue can be found in the way she is introduced to the reader:

He fond in the pavyloun

The Kynges doughter of Olyroun,

Dame Tryamour that hyghte;

Her fadyr was Kyng of Fayrye (277-80)

Tryamour is a fairy princess, which gives her an inherently exotic quality and might allow her more transgressive behaviour than a human lady (Saunders 108). When Launfal encounters the two ladies that lead him to his fairy mistress, he is sitting under a tree during a summer morning (Launfal 211-31), a situation which often leads to visitations by fairies and magical creatures (Sir Orfeo 65 and note).9 Combined with the splendour of Tryamour's pavilion and bed (Launfal 265-67), the indescribability of her magnificent clothing (299-300), and her beauty, this setting gives the whole scene a dreamlike, otherworldly quality. It only adds to Tryamour's exotic nature that she dares present herself topless in a forest clearing where — at least theoretically—any given number of people might find her. These matters make her more desirable than the treacherous, human Guinevere.

If we concede that the lady's exposed breasts might not be the (only) erotic focal point of the forest meeting, however, we need to look for it elsewhere. In his article "'Some Like it Hot': The Medieval Eroticism of Heat," Robert Rouse argues that the answer can be found in the heat of the day that is so frequently

\footnotetext{
${ }^{9}$ All quotations refer to Shepherd's edition of Sir Orfeo.
} 
referred to throughout Launfal's ride to the forest and his meeting with his beloved. The poet tells us that "the wether was hot the underntyde" (220) when Launfal sets out, and a few lines later the knight takes off his cloak "for hete of the wedere" (223). In the same fashion, Tryamour's state of undress is blamed on the heat (289). Rouse suggests that this connection between heat and romantic scenes would have read as erotic to a medieval audience. While the season traditionally connected with chaste, courtly romance is spring, especially May (77), "[s]ummer, and the hot weather that the season brings, seem to occupy a particular place in the rhetoric of love and desire" (76). In several texts the heat of summer is decried as causing impure (i.e. lustful) thoughts and making people more aware of their sexual desires (76). Rouse links this association back to the theory of the four humours, which was central to the leading medieval understanding of the body. Heat and summer are connected with yellow bile and a choleric temperament. Usually, women are thought to be of a cooler disposition, so an excessively "hot" woman would exhibit more sexually forward (i.e. masculine) traits (Rouse 79-80). Following this line of reasoning, Rouse suggests that Tryamour's actions, her striptease and active wooing of Launfal, might have made her seem "hot" and thus inherently erotic to a medieval audience (80). Thus it would not be the fairy's naked body itself, but her very nature and the trappings of the exotic summer scene that are responsible for the eroticism of this encounter.

Despite Rouse's and Bynum's assertions, however, the erotic appeal of Tryamour's nakedness cannot be entirely disregarded, especially when we take into consideration the romance's source material. The Middle English Sir Launfal is based on a French romance by Marie de France called Lanval. While some of the Middle English episodes can be traced back to a different source, the scenes relevant to this paper already appear in Marie's text and consequently in other Middle English redactions of the same. Comparing the meeting scene between Launfal (or his counterparts) and Tryamour in the different versions, Amanda Hopkins finds that the fairy's nakedness becomes less subtle and more pronounced in later texts (66). In Marie's twelfth-century version, Tryamour is still wearing a shift and has drawn an expensive mantle over herself for warmth (Hopkins 64); in Launfal, as stated above, not only does she not wear a shift anymore, she has taken off her cloak because of the heat, putting more emphasis on her nakedness. In one of the latest redactions of the text, Sir Lambewell, traditionally dated to around the year $1500,{ }^{10}$ the scene becomes even more explicit, adding that Tryamour's clothing is lying next to her, thus eradicating any subtlety from the revealing of her naked state (Hopkins 66). While Hopkins goes into some detail regarding the reasons for such changes, the takeaway for this paper is that even though Tryamour's halfnaked body might not be the only, maybe not even the primary, factor for the

\footnotetext{
${ }^{10}$ For further discussion of the different Middle English redactions of Lanval, as well as questions regarding authorship and dating, see Spearing 117-56.
} 
eroticism in this scene, it undoubtedly plays a part, and was identified that way by the Middle English redactors of the Old French romance.

Romance in Bed and Bath

After examining this example of blatant, possibly even transgressive nakedness, we should take a look at other situations where naked bodies might be expected more readily: the bed and the bath. As explained above, it is not entirely clear whether sleeping and bathing actually involved taking off all of one's clothing, especially in front of other people. Therefore, when talking about scenes involving characters in bed or taking a bath, we must examine carefully whether definite nakedness is involved, and how it is connected to the scenes' eroticism, if any is suggested.

There are many romances in which characters share a bed at some point, though most of these scenes fall into one of two categories. The first possibility is that the characters are married, and their sleeping together is a natural state of affairs. Sometimes these scenes involve sex (especially on wedding nights), but often they just offer one possible setting for plot elements to happen. In a scene from Havelok, which I will discuss in further detail in the subsection "Identity," the titular character and his wife sleep in the same bed, when they both have dream visions (1247-1312). When they wake up, they are conveniently placed next to each other and can discuss their respective experience. For the purposes of this paper, the fact that they are sharing a bed is incidental, serving mostly as a framing device for their visions. Also, the fact that they are most likely naked at the time does not convey any inherent eroticism; rather, it serves a very specific function for the plot (cf. below). In cases like this one, the characters' nakedness, if it exists, is either incidental, due to circumstance, or instrumental to the plot. Either way it does not really add to our deeper understanding of different functions of nakedness.

The second type of bedroom scene, which is found more commonly in Middle English romances, is a scene involving two lovers sleeping together. An example for this would be the first night Launfal spends with Tryamour, in which "For play lytyll they sclepte" (Launfal 349). Here we must assume that both characters are at least partially naked, but the erotic nature of the scene derives from the actual love-making, not necessarily from the fact that both participants have taken off their clothes. Another example can be found in Geoffrey Chaucer's Troilus and Criseyde, ${ }^{11}$ when the eponymous couple sleep together for the first time, although here the detailed description of Criseyde's naked body adds significantly to the scene's eroticism (Troilus III, 1247-53). ${ }^{12}$ But no matter whether a bedroom scene

\footnotetext{
11 All quotations refer to Benson's edition of Troilus and Criseyde.

${ }^{12}$ For a closer analysis of the eroticism of this scene see Hopkins 61.
} 
between two lovers involves explicit mention of nakedness and eroticised bodies or not, their presence, assumed or otherwise, is not surprising, given the context.

Much more interesting for our study are cases which fall into neither category, where two unmarried characters who are not lovers share a bed, or one character lies in bed while others watch. One such constellation occurs in similar iterations in The Avonyng of Arthur and Sir Gawain and the Carle of Carlisle. ${ }^{13}$ In both these romances, a man is made to lie in bed next to a married woman, under strict instructions not to let the situation escalate sexually. While this setup sounds as though it might hold some erotic potential, the mood is subverted by the surrounding circumstances.

In Avouyng, Sir Baldwin has made three vows, the third of which is never to be jealous of his wife, and King Arthur has devised a test to see if Baldwin will be true to his word. When Arthur and his court are staying at Baldwin's castle, the king orders his host to go hunting, and instructs one of the hunters to make sure the party will be back early the next morning. Arthur's plan is to order one of his knights to share a bed with Baldwin's wife, but not to touch her on pain of death. In the morning, the lady's husband will return and catch the two in flagrante delicto, which—so Arthur's hope—will make him jealous and angry, thus breaking his vow.

At night, while the hunting party is still away, Arthur is allowed into the lady's bedchamber, when he tells her that he will not sully her reputation. The lady has already gone to bed, although her maids are still with her, so Arthur sits down at the foot of the bed (835) and explains that he does not intent to hurt her, he is merely trying to settle a bet (841-44). The king has brought a knight who will pose as her lover with him to the chamber. The ensuing scene has to be quoted at length to understand its full effect.

Thenne the Kyng sayd to his knyghte,

"Sone that thou were undyghte,

And in yondur bedde ryghte!

Hie the gud spede!"

The knyghte did as he him bade,

And qwenne ho se him unclad

Then the Lady wex drede,

Worlyke in wede.

He sayd, "Lye downe prevely hur by,

Butte neghe noghte thou that Lady;

For and thou do, thou schall dey

For thi derfe dede;

13 All quotations refer to Hahn's editions of The Avonyng of Arthur and Sir Gawain and the Carle of Carlisle. 
Ne noghte so hardy thou stur, ${ }^{14}$

Ne onus turne the to hus."

The tother sayd, "Nay, sur!"

For him hade he drede.

Thenne the Kyng asshet a chekkere,

And cald a damsel dere;

Downe thay sette hom in fere

Opon the bedside. (845-64)

Although this scene has two unmarried naked people sharing a bed, it could not be further from erotic. The complete unconcern with which King Arthur orders his knight to strip, threatens to kill him if he disobeys, and then proceeds to play chess while sitting on the side of the bed is juxtaposed with the very clear discomfort of the lady and her pseudo-paramour, creating a strong comedic effect. The knight is explicitly barred from arousal by Arthur's command (857), which further drains any possible eroticism from the scene, and he takes care not to look under the cover (867-72). Throughout the night, the two supposed lovers lie next to each other, naked under the sheets, ${ }^{15}$ but the only "play" (a common Middle English euphemism for sex, e.g. Carle 486) that occurs is the game of chess between Arthur and one of the handmaidens (869).

The script is flipped somewhat in The Carle of Carlisle, because here the hero has to spend the night next to another man's wife without allowing himself any sexual stirring. Throughout the romance, the lowly Carle tests the courtesy of Gawain who is staying at his castle. In every situation that presents itself, Gawain follows his host's instructions to the letter, even though he is socially above the Carle's station. When the Carle discovers that Gawain is strongly attracted to his (the Carle's) wife, he devises a final test: Gawain must join the Carle's wife in bed, and embrace and kiss her while her husband watches. Gawain is undressed by the Carle's servants (452-53), and is only too eager to follow his host's commands (457-64). He climbs into the bed "fast and that good spede" (462), and kisses the lady, which her husband observes with satisfaction (464-65). However, "When Gawen wolde have doun the prevey far, / Then seyd the Carle, 'Whoo ther! / That game I the forbade"” (466-68). Instead, he allows Gawain to spend the night with his beautiful daughter, as a reward for the knight's courtesy. ${ }^{16}$

\footnotetext{
${ }^{14}$ Hahn translates this as "Nor be so bold that you become aroused."

15 Although Baldwin's wife is described as "worlyke in wede," literally "excellent in clothing" (Avonyng 852), this is most likely a standard phrase to describe her beauty and virtue, not a comment on her current state of dress.

${ }^{16}$ Both episodes described above raise a variety of issues concerning the commodification of female bodies, agency, consent in romances, and more, which cannot be discussed in this paper, but deserve further study.
} 
This scene has a lot of potential for erotic tension. We learn that Gawain is strongly attracted to the Carle's wife, so much so that the Carle is able to detect his thoughts and gently mock him for them (406-14), and once the two "lovers" are naked in bed together, Gawain even tries to initiate sexual intercourse. Nevertheless, the fact that all this is taking place under the knowing eyes of the Carle, who watches the unfolding events like a puppet master (409-14, 465), destroys any erotic potential the scene might have had and draws it into the comical. ${ }^{17}$

To sum up, there are several different ways in which scenes involving nakedness in the bedroom can play out. If the bed is shared between two lovers, married or otherwise, we are likely to find sexualised naked bodies. However, being in bed (and consequently probably naked) can also be used as a convenient setting to further a romance's plot, in which case it does not necessarily depend on or conjure up eroticism. And sometimes the expectation of erotic tension created by the naked characters in a bedroom scene is used in some other way, for example to achieve a comedic effect through subversion.

Much rarer than bedroom scenes, though, are scenes in which characters take a bath. Elizabeth Archibald has written a whole article on the question, titled "Did Knights have Baths?" in which she evaluates evidence from a wide range of texts. Archibald's first observation is that scholars' claims that bathing scenes, often with erotic overtones, are common in medieval English literature suffer from a lack of evidence in the sources. In fact, she finds that the MED lists hardly any instances of bath or bathen in Middle English romances (101-02). Furthermore, she asserts that the "link between baths and sex is lacking in Middle English romance, in spite of the comments of [some] social historians" (Archibald 108). So what do the few baths that we do find in the romances look like?

The Middle English Ywain and Gawain, ${ }^{18}$ which adapts Chrétien de Troyes' French Yvain, le Chevalier au Lion, has two instances of the titular knight taking a bath, or, to be more precise, being bathed. The first one occurs when Ywain is hiding in the castle of the knight who used to protect the magical spring. Lunet, the maid who saved Ywain's life upon his arrival to the castle, has convinced her lady, Alundyne, to receive Ywain, and to consider him as a possible new husband and protector. To prepare the knight for this meeting, Lunet gives him a bath and new clothing:

Bilive sho gert Syr Ywaine bath

And cled him sethin in gude scarlet

Forord wele and with gold fret,

\footnotetext{
17 Similar constellations occur in other romances, most prominently Sir Gawain and the Green Knight, when Lady Bertilak comes to Gawain's room while he is lying in bed, possibly naked, and sits down next to the knight, trying to seduce him. The different possible implications of those scenes have been studied many times, most relevantly for this paper by Hopkins (56).

18 All quotations refer to Shepherd's edition of Ywain and Gawain.
} 
A girdel ful riche for the nanes

Of perry and of preciows stanes. (1102-06)

These lines do not give any explicit information on how this bath takes place, whether Lunet only leads Ywain into a chamber where a bath has been prepared for him or whether she personally washes the-presumably naked-knight. But even if the line "sho gert Ywain bath" entailed a completely undressed man being attended during his bath by a woman, the scene does not hold any erotic potential. For one, it is glossed over quickly, seemingly only providing a precursor for Ywain's being outfitted in new, splendid clothing, which is described in much greater detail. Furthermore, Lunet makes it very clear that she does not harbour any romantic interest for the Arthurian knight. It is true that the maid saves Ywain when he is caught between the castle's portcullises with his enemies about to discover him. She presents him with a magic ring of invisibility and hides him from his enemies in her own bed. She does not join him there, however; indeed, she only intends to facilitate a marriage between her lady Alundyne and Ywain (see esp. 915-18). Perhaps a medieval audience would not have expected a servant woman to be a viable romantic partner for a noble knight like Ywain, the son of king Urien, but even if such a connection had been conceivable, it is never acted upon, and thus the bathing scene seems a mere practical matter, not a possibility for erotic interaction.

Later in the same text, Ywain is once again bathed by a lady's handmaiden and once again there does not appear to be any sexual tension between the two. The scene occurs after Ywain has spent several years living in a forest, naked and insane. ${ }^{19}$ He has fallen asleep on the forest floor when a lady rides along with her two handmaidens, who take pity on him and decide to cure him with a magical ointment. One of the handmaidens is tasked with anointing Ywain, bringing him new clothing, and leading him to the lady's castle. Once there,

sho gert him washe and bathe

And gaf him mete and drink of main,

Til he had geten his might ogayn. (1864-66)

Not only is this practically the exact same phrasing used 800 lines earlier; the circumstance seems to be exactly the same as well. Although the maid has watched the naked knight sleeping, and anointed "his body ilka dele" (1780) with the curative ointment, she does not seem to have any sexual interest in him. Here, the bath is equivalent to food and drink, restoring Ywain to his former strength, and washing away the signs of his time spent in the woods and in madness.

In Sir Orfeo, we find another example of such a cleansing bath in circumstances that closely resemble Ywain's. After King Orfeo returns from living in the woods for ten years and rescuing his beloved wife from the fairy realm, he looks so

${ }^{19}$ See further below. 
shabby that none of his former advisors recognises him. However, once he reveals his true identity, he receives a bath and new clothing.

To chaumber thai ladde him als bilive

And bathed him, and schaved his berd,

And tired him as a king apert. (584-86)

Once again, the bath is merely a part of the required process to restore Orfeo to his former state and there is no mention of nakedness or the presence or absence of servants.

What these examples show is that Elizabeth Archibald appears to be right in asserting that baths did not occur too often in Middle English romances, and where they did, they hardly ever had sexual connotations (102-03). The cliché of romances teeming with erotic bathing ${ }^{20}$ is very much based on continental texts, and in the rare instances where Middle English romances actually do mention baths, they are remnants of continental originals (Archibald 113). The bathing scenes described above serve clear narrative functions of cleansing and restoration, but are never used to induce a romantic relationship, even where they involve a woman washing the naked body of a knight.

So far, we have discovered textual evidence for the fact that naked bodies can be signals for eroticism and sexuality, as is arguably the case with Tryamour, but the situation is not always so clear. Even scenes involving characters in bed or in a bath-and thus arguably nudity-do not necessarily entail occurrences of romance or sex. This raises the question what other functions the depictions of nakedness might serve in the context of Middle English romances.

\section{Poverty}

Going back to the opening lines of Havelok, we come across the first category of non-erotic nakedness that will be examined in this paper: nakedness in the context of poverty. Throughout the Middle Ages, but especially with the rise of the mendicant orders, self-imposed poverty was strongly connected to spiritual purity. One expression of this ideal took the form of simple clothing. Monastic orders gave up worldly luxury to focus on religious devotion, and to live in poverty was regarded as a form of imitatio Christi (Rahner 178). While those who had no choice but to live in poverty were not typically viewed through the same lens, charity was considered a central Christian value throughout the Middle Ages, and helping the needy was seen as a worthy path towards salvation. According to Robert Jütte, beggars, the sick, and the poor could show themselves "naked" (likely meaning insufficiently clothed) in public with impunity, using their poor appearance to inspire pity and Christian charity in their fellow men, making them the only people for whom public nakedness was not a moral detriment (119).

${ }^{20}$ Discussed in Archibald 102. 
In Havelok, the eponymous hero grows up in great poverty, which is frequently expressed through his state of (un-)dress. In the beginning of the poem (quoted above), we learn about Havelok that "Wil he was litel he yede ful naked" (6). The poet follows this line with a brief discussion of Havelok's virtue and courage in battle $(7-10,23-26)$, before he begins the story proper. Thus our protagonist's very first description calls him "naked" in his youth. This lends a certain weight to this piece of information, making it one of Havelok's defining characteristics throughout the poem. Whether "naked" in this case would have been interpreted by a medieval audience as literal nakedness or being clothed in rags is not quite clear, but at numerous points in the story, Havelok is described as either "naked" (e.g. 853) or "almest naked" (962), sometimes referring to full, sometimes to clothed nakedness, but always highlighting his inadequate state of dress.

No matter which specific definition the nakedness in these scenes fulfils, the question remains: what function does it serve? On a surface level, Havelok's "naked" body is a visual representation of his poverty. While his foster father Grim provides the family with food, he is not able to give his ward sufficient clothing. Even after finding employment with the cook Bertram, Havelok still lacks the means to dress himself suitably. Digging deeper, however, this poverty and consequent nakedness is not a simple story element propelling the plot forward or illustrating a point. Rather, it seems designed to evoke the audience's pity and sympathy for Havelok.

When Grim decides to send his foster-son off to Lincoln, he laments, "But wo is me thou art so naked" (853). He cannot afford to give the young man more than a plain cloak made out of his boat's sail as a parting gift (854-58). Havelok has to go into town barfot (862), without stockings or shoes (860), a state of dress that was highly unacceptable unless you were a beggar. ${ }^{21}$ This display of extreme poverty combines with Havelok's enduring gratitude in the face of his adversity to make him appear very favourable in the eyes of the audience. Another example of Havelok's nakedness inciting pity occurs when he works as Bertram's servant. The young prince is extremely kind and generous towards everyone he meets, but his ragged, dirty clothing stands in stark contrast to his virtuous character and beautiful appearance. Eventually, Bertram "bigan of him to rewe" ("takes pity on him," 967), and buys Havelok new clothes.

Somewhat connected to this aspect, there is another, spiritual component to Havelok's nakedness. Havelok is presented to us as a perfect king, right from the beginning of the romance. At the very beginning of the tale, we already hear about the young man's virtues as a courageous knight, and good, worthy man. The story proper starts with descriptions of the perfect kings Athelwold of England (27-109), and, a little later, Birkabeyn of Denmark (338-47), and ends with a description of Havelok's own reign as benevolent, exemplary ruler. So when we

${ }^{21}$ Even bathers, who were not held in very high regard in medieval society, were explicitly forbidden from going out into the street barefoot (Brander 292). 
meet Havelok as a child, he is naked and living in poverty, but destined to be the saviour and perfect king of his people. From a medieval perspective, such a characterisation would very likely resemble that of Jesus Christ. Jesus was born in a lowly stable, and many images of the baby Jesus show him naked. As discussed in the introduction, most scholars today assume that this depiction was chosen to highlight Christ's human nature, not any sense of poverty (e.g. Duerr 207), but the fact remains that in the medieval mind, this image of Christ as a naked child, poor, but destined to be the saviour of his people, would have been very present. This association strengthens the function of Havelok's characterisation as a role model and mantra for English kings: Be modest, be content with your lot in life, follow in the footsteps of Christ, and your reign will be prosperous.

A slightly different evaluation of nakedness born out of poverty can be found in Sir Launfal. While the word "naked" is not used once in the entire tale, there are several instances of people in poor or inadequate clothing, which (as established above) would have been included in the medieval concept of "nakedness". One of them occurs after Launfal has taken up residence in Cærleon.

When Launfal leaves King Arthur's court, the king gives him a purse to live on (79-84) but within a year, the knight has fallen into debt due to spending savagelych (130). The ensuing consequences are described almost exclusively through lack of clothing. Arthur's nephews, who had accompanied Launfal to the town of Cærleon, take their leave of him after he loses all his money, explaining:

Syr, our robes beth to-rent,

And your tresuor ys all y-spent,

And we goth evyll y-dyght. (139-41)

The deciding factor for their leaving Launfal is not that he cannot provide them food, sport, or treasure, but that they do not have any adequate clothes left, and the knight is unable to buy them new ones. The interaction demonstrates the significance placed on proper attire in the romance of Launfal, and likely among its audiences.

This trend is compounded a few lines later. A week after Launfal's servants leave him, the mayor of Cærleon hosts a great feast, from which the knight is excluded due to his poverty (187-88). When the mayor's daughter decides to invite him regardless, Launfal declines, saying that he has "no herte" (195) to dine in company. He explains that he has not eaten in three days (197-98) and recounts:

Today to cherche I wolde have gon,

But me fawtede hosyn and schon, ${ }^{22}$

Clenly brech and scherte-

\footnotetext{
22 The expression "me fawtede hosyn and schon," mirrors closely a line from Havelok, "Havede neyther hosen ne shon" (860), which is how Havelok is described after Grim has given him his cloak made out of sail. It follows directly after Grim exclaims how his charge was "so naked" (853), which further strengthens my argument that Launfal's poor state of dress can be classified as nakedness.
} 
And for defawte of clothynge

Ne myghte I yn wyth the peple thrynge-

No wonder though me smerte. (199-204)

What these two passages demonstrate is how embarrassing it feels to Launfal and his companions to be unable to dress in the proper manner of their social rank. Their inadequate clothing, their "nakedness," exposes them to ridicule and shame. When Launfal's companions return to court, they feel it necessary to explain their poor state of dress to the king, and because they have promised Launfal that they would not expose his poverty, they come up with a wild excuse (166-74). Of course, this might only serve to demonstrate their loyalty to their former lord, but it still shows that appearing at court improperly dressed warrants a lengthy explanation.

Launfal's exclusion from the feast is explained with the sentence "Lyte men of him tolde" (189), ${ }^{23}$ which highlights how much his poverty has demeaned him in the eyes of the townspeople. This contempt is further illustrated in another episode, after Launfal returns from his meeting with Tryamour in the forest. Tryamour's servant, Gyfré, rides into Cærleon with the riches the fairy princess promised her lover, but since he does not know where to find Launfal, he asks a boy if he knows where the knight resides. The answer is rather telling: "Nys he but a wrecche; / What that any man of hym recche?" (394-95). ${ }^{24}$

The image presented here of poverty and consequent nakedness is very different from that in Havelok. Havelok's nakedness causes people to pity him and offer him clothes (thus Grim in 11. 853-59 and Bertram in 1l. 967-70). He is depicted as innocent, morally good, and-arguably_saintly, if not Christlike in the face of adversity. By contrast, Launfal's poverty and nakedness are met with derision and contempt from the people in Cærleon. His social isolation and hunger might cause an audience to pity him, but his situation is not presented as unambiguously deserving of it. Whether or not Launfal's destitution makes him more sympathetic depends on how one interprets his excessive spending. At the beginning of the poem, we learn that Launfal is renowned for giving generous gifts to his friends and servants (28-36). This largesse (31) even impresses Arthur so much that he makes Launfal his steward. However, it does not become clear from the story whether it is also his largesse that causes the knight to spend all of his money in a single year. All we are told is "So savagelych hys good he besette / That he ward yn greet dette, / Ryght yn the ferst yere" (130-32), which does not yield any definitive information either way. The question of generosity and gift-giving in Sir Launfal has been much discussed in academic discourse, but for the purposes of this paper, I merely want to stress that Launfal's destitution and subsequent "nakedness" do not make his character appear in an unequivocally good or bad light.

\footnotetext{
${ }^{23}$ Shepherd glosses this as "people reckoned him of little account."

${ }^{24}$ Shepherd gives as translation: "He is nothing but a wretch; what does any man care of him?".
} 
Nakedness born out of poverty, therefore, can serve to inform the audience's moral judgement of a character, although the specific results of this evaluation depend heavily on the surrounding circumstances.

\section{Identity}

The final aspect of nakedness that is to be examined here is that of identity. Probably the best and most obvious example of this can be found in Ywain, preceding the bathing scenes discussed above. After Ywain's wife leaves him because he has broken a promise to her, Ywain goes mad with grief and self-loathing and runs into the forest, where he lives like an animal for "a grete sesowne" (1667), an unspecified amount of time. There is no explicit mention of Ywain shedding his clothes, but after living off roots and raw game for a while, he happens to come across a hermitage and we read "The ermyte saw and sone was war / a naked man ...” (1674). The Old French Yvain provides more detail for this particular scene, describing how the knight tears his clothes to shreds in despair before running away into the wilderness (330). ${ }^{25}$ Thus it seems reasonable to assume that when he lives in the forest, Ywain is, in fact, entirely naked.

In her article "Körper und Identität: Geschlechtsspezifische Codierung von Nacktheit im höfischen Roman um 1200," Silke Winst analyses the corresponding scene in Hartmann von Aue's Middle High German rendition of Chrétien de Troyes' Yvain (Iwein). ${ }^{26}$ She comes to the conclusion that Ywain's nakedness is strongly connected to his identity as a knight. When he breaks his vow to his wife Alundyne, he commits a transgression of the knightly values of duty and honour, and he spends the rest of the romance trying to re-establish his honour and his character. This "crisis of identity" (Winst 349) is what Ywain's nakedness emphasises. Without any social markers to identify him by, he becomes aimless, unthinking, no longer bound to human reason, and lives like an animal. Only after the lady with her two handmaidens happens on the sleeping (naked) knight, whom they recognise by a scar on his face, is there a chance for Ywain to regain knowledge of his true character.

As mentioned above, Ywain's restoration is achieved when one of the lady's maids returns to the sleeping knight with a curative ointment, which she rubs on "his body ilka dele" (Ywain 1780). After doing so, the woman hides and keeps watch over Ywain, making sure he finds the clothes she has left next to him, and then pretends to happen upon the knight coincidentally once he is dressed. Looking at this scene from a modern perspective, it seems to have great erotic potential, and Albrecht Classen argues that indeed there is some sexual tension in the

\footnotetext{
25 Quotations refer to the modern English prose translation The Knight with the Lion (Yvain) by Kibler.

${ }^{26}$ For ease of reference, I will not differentiate in spelling between the Middle High German Iwein, the Old French Yvain and the Middle English Ywain, but use the normalised Middle English form of the name and make it explicit when I refer to one of his literary counterparts.
} 
Middle High German version of this encounter ("Naked Men" 157). The Old French source takes it one step further. The encounter between Ywain and the maid is described in great detail:

She rubbed his temples and his forehead and his entire body down to his toes. She rubbed his temples and his whole body so vigorously under the hot sun that she expelled the madness and melancholy from his brain ... (Yvain 333)

Not only does Chrétien repeatedly emphasise that she massages Ywain's "whole body," there is also-seemingly randomly-a reference to the heat of that particular day. As established above, heat could have a very strong connection to sexual desire, especially female sexual desire, in medieval literature, which makes it even more likely that this scene would have been perceived to have erotic overtones.

However, these subtleties seem to be entirely absent from the Middle English text. The anointing is reduced to two short lines: "Sho enoynt hys heved wele / And his body ilka dele." (1779-80), and when the maid hides and watches Ywain until he wakes up, this is relegated to an aside "Than he wakend of his slepe / (The maiden to him toke gude kepe)" (1789-90). In the Middle High German poem, we get more insight into the maid's thought process, and Classen interprets her actions as holding a certain amount of thinly veiled erotic voyeurism ("Naked Men" 156-57). The Middle English rendering of Yvain is generally regarded to be less introspective and detailed than its French source (and German counterpart), so subtle subtext might have been omitted for the sake of moving the plot along, in the knowledge that the audience would be able to read between the lines. However, it appears clear that what they would have found there is not the erotic tension which seems to underlie the Continental versions of the story. Rather, Ywain's nakedness, his encounter with the three ladies and subsequent restoration to sanity (and clothing), seems to reflect exclusively on his loss and rediscovery of identity and knightly virtue.

Sir Orfeo contains a thematic parallel to this scene that should be mentioned here. When Queen Heurodis is kidnapped by fairies, King Orfeo is so bereft that he decides to leave his kingdom to live in the woods. While he does not run away in immediate anguish but takes his leave of his councillors and settles his affairs, he discards his royal robes and dons a plain pilgrim's mantle instead (227-28). His loss of status, as symbolised by his loss of luxurious garments, is thrown into relief in a passage that explicitly contrasts Orfeo's simple existence in the forest with the splendours of his former life:

He that hadde y-werd the fowe griis,

And on bed the purper biis -

Now on hard hethe he lith,

With leves and gresse he him writh. (241-44) 
Orfeo is not called "naked," and his state of dress is never described as poor enough to fully justify his inclusion in that category, but the striking parallels with Ywain still help to illuminate the function of nakedness as regards identity.

In Middle English literature in general, and romances in particular, a character's identity is often established or at least underscored by the kind of clothing he or she wears. ${ }^{27}$ It stands to reason, therefore, that a loss of identity would go hand in hand with a loss of clothing, even to the point of complete nakedness. Once the characters return to their rightful place in society (Ywain upon being cured, Orfeo after he rescues his wife and reveals himself to his loyal councillors), they also immediately return to a socially appropriate state of dress (Ywain 1803; Orfeo 584-86).

In the two examples above, nakedness or inadequate clothing marks a crisis of identity that the heroes need to overcome, but nakedness can also have a revealing function. For this, we need to return to Havelok. Havelok, the rightful heir to the throne of Denmark, spends the majority of the romance hiding his true identity, but on three occasions his royal nature is revealed, once even saving his life.

When King Birkabeyn dies, the wicked Earl Godard, who is supposed to serve as Havelok's guardian, instead orders the young boy to be killed, so he can take the kingdom for himself. His thrall, the fisherman Grim, is told to drown the boy in the sea and obediently takes him to his home, where he binds and gags him. At night, when Grim and his wife rise to carry out the deed, they discover that the room in which Havelok is sleeping is "Al-so brith so it were day" (589). A beam of light is issuing from the young boy's mouth. When the two strip him looking to explain this miracle, they discover a kynemerk on his shoulder (604). This cruciform birthmark also gleams bright and beautiful (605). Grim and his wife interpret it and the mysterious light to mean that Havelok is indeed the son of king Birkabeyn and heir to the Danish throne. This discovery causes the pair to defy Godard's orders, and instead of executing Havelok, they decide to save him. Shepherd explains that since Havelok should be king by divine right, Grim and his wife have to fear God's judgement should they kill him (604 and note).

The second time Havelok's birthmark is revealed, albeit under less dramatic circumstances, occurs after he has been forcibly married to Goldeboru, the rightful heiress to the kingdom of England, by her guardian, the wicked Earl Godrich. Godrich thinks that Havelok, who works for the castle cook, is nothing but a slave and thus if Goldeboru marries him, she will forfeit her right to the throne and Godrich himself can rule unimpeded. After the wedding, Goldeboru feels betrayed and disheartened at having been married beneath her social rank, but in the first night, she, too, discovers the light coming from Havelok's mouth and

\footnotetext{
${ }^{27}$ For discussions of the connection between clothing and identity in medieval literature in general, see Smith and Denny-Brown.
} 
"On his shuldre, of gold red / She saw a swithe noble croiz" (1262-63).28 As soon as she has made this discovery, an angel appears to her, telling her about Havelok's true nature and that he is fated to defeat their foes and become king of Denmark and England.

Finally, when Havelok and Goldeboru go to Denmark to reclaim the kingdom, they are hosted by a Danish nobleman, Lord Ubbe, and Havelok's royal nature is revealed for the third time. When Havelok, Goldeboru, and their companions meet Ubbe, they claim to be merchants and impress him with their strength and fighting prowess when they fend off a band of thieves that attacks Ubbe's house during the night. Out of gratitude, Ubbe gives Havelok and his companions the chamber adjacent to his own, and when he wakes up in the middle of the night, he sees a mysterious light shining from his guests' room. Ubbe calls his men to witness this miracle and they go into the chamber to investigate, where they find Havelok, the miraculous light shining out of his mouth. The young prince and his companions are asleep and the scene is described as follows:

And Havelok lay on his lift side,

In his armes his brithe bride;

Bi the pappes he leyen naked.

So faire two weren nevere maked

In a bed to lyen samen;

The knithes thouth of hem god gamen,

Hem for-to shewe and loken to.

Rith al-so he stoden alle so,

And his bac was toward hem went,

So weren he war of a croiz ful gent

On his rith shuldre-swithe brith,

Brither than gold ageyn the lith-

So that he wiste, heye and lowe,

That it was kunrik that he sawe.

It sparkede and ful brith shon

So doth the gode charbuncle-ston (2130-45)

Immediately, Ubbe and his men understand that Havelok is the son of King Birkabeyn. They swear him fealty and declare that they will support his fight against Godard.

In all three scenes described above, the discovery of Havelok's identity is dependent on the revealing of his naked body. Not only the royal birthmark on his shoulder, but also his beauty are understood as signs of his royal birth: "So this

\footnotetext{
${ }^{28}$ As an aside, this scene would be an example of tacit nakedness in bed. Grim and his wife have to strip Havelok to see his birthmark; there is an explicit mention made of his nakedness on a later occasion, but not here. Quite possibly, two newlyweds sharing a bed for the first time were so clearly expected to be naked that it does not merit explicit mention.
} 
man, that is so fayr, / Als Birkabeyn: he is hise eyr!" (2156-57). At the same time, Havelok's lack of appropriate clothing also plays a part in keeping his identity secret. As mentioned above, when he goes to Lincoln, Bertram the cook takes pity on Havelok and gives him new clothes (967-70). As soon as Havelok is dressed in this new attire, the people of Lincoln are convinced that he is sufficiently beautiful to be a king:

It was nevere man that yemede

In kinneriche that so wel semede

King or cayser for-to be,

Than he was shrid—so semede he. (975-78)

It seems that Havelok's nobility can be gleamed from the physical beauty of his body, but it only fully reveals itself when that body is either dressed in appropriately fine clothing or stripped bare. The "ful and swithe wicke" attire Havelok is forced to wear in his poverty (965) sufficiently conceals his royal nature to convince the Earl Godrich that he is nothing but a thrall (1095), which is why he deems him the perfect match to disenfranchise Goldeboru.

A similar thing happens to Orfeo, when he appears before the fairy king to bargain for the return of his wife. After Orfeo performs a beautiful piece of music on his magical harp, the fairy king promises to grant him any wish as payment, so the knight asks to take Heurodis back with him to his world. The Fairy king refuses however, declaring

... that nought nere!

A sori couple of you it were-

For thou art lene, rowe and blac,

And she is lovesum, withouten lac;

A lothlich thing it were, forthi,

To sen hir in thi compayni. (Orfeo 457-62)

After living in the forest for ten years, and with no sign of his royal status left, Orfeo is not deemed of the appropriate station to be given such a beautiful and worthy lady as Dame Heurodis.

The contrast between physical beauty and poor clothing in Havelok and Orfeo elicits responses revealing the role of both in the assertion of social status in these texts. Neither Havelok's kindness and generosity, which make him well-liked by all the people of Lincoln (e.g. Havelok 957), nor Orfeo's ethereally beautiful harp-play (Orfeo 435-52) is enough to convince these protagonists' adversaries of their worth. Their true character, and thus their true identity, remains hidden behind their insufficient exteriors.

To sum up, it appears that nakedness, with clothing and without, can have complex implications for the identity of romance characters. On the one hand, it can be used as shorthand for a crisis or loss of identity. On the other, it can reveal 
a character's true nature by stripping away an impeding disguise and showing their true beauty or unique features. In pursuit of these ends, nakedness serves absolutely no erotic function and the naked body is used as a symbol of identity, not sexuality.

\section{Conclusion}

As difficult as it is to come to definitive conclusions on the social history of nakedness, it is equally challenging to do justice to the semiotic nuances of its literary counterpart from our modern perspective. We tend to overvalue the sexual significance of nakedness and miss or misinterpret other clues that might have created an erotic setting in the minds of medieval readers. Despite these insufficiencies, however, what has become clear is that there are many different aspects of nakedness, which were used to a variety of effects. While there are a number of cases in which nakedness is indeed used to heighten erotic frisson, it can also serve to inform a moral judgement of a character, by making the audience feel sympathetic or disdainful towards them, or it can highlight discrepancies in a character's identity.

So far, there has not been much scholarship on this particular subject, and this paper only provides a first, general approach, but some aspects already stand out, which could yield interesting results upon further study. One possible approach would be to look at different instances of nakedness with a focus on gender. Most of the scenes examined in this paper depict naked men, so a question that could be asked in the future is whether naked women were treated differently. Does nakedness become inherently more erotic when exhibited by, or inflicted upon female characters? And if they are sexualised, can they use it to their advantage, as Tryamour does, or does her otherworldly nature grant the fairy princess privileges which would be withheld from other ladies? Another possible point for study might be the relationships between continental and English texts. While there has been a lot of scholarship on cultural transfer in romances in general, this specific aspect has not yet been examined on a larger scale. Perhaps the small differences that I have been able to highlight hint at wider discrepancies, which can give some insight into cultural differences between medieval European societies.

Ultimately, studying the connections between the treatment of a potentially controversial subject such as nakedness in society and its place in literature might be able to produce some answers to questions of authorship and audiences. In the pursuit of such insights, we should be careful not to project literary attitudes towards nakedness and sexuality onto medieval society as a whole. After all, the sexually charged mass media in some modern countries does not necessarily reflect their conservative political discourse. It is clear that the connections between those two are complex and would probably be hard to reconstruct from a distance of several centuries. Nevertheless, understanding the varied and nuanced ways in 
which naked bodies are portrayed in Middle English romances can add to the appreciation of the Middle Ages as the diverse and complex epoch that it was.

\section{Works Cited}

Archibald, Elizabeth. "Did Knights have Baths? The Absence of Bathing in Middle English Romance." Cultural Encounters in the Romance of Medieval England. Ed. Corinne Saunders. Cambridge: Brewer, 2005. 101-17. Studies in Medieval Romance 2.

Benson, Larry D., ed. Troilus and Criseyde. The Riverside Chaucer. 3rd edition. Boston: Houghton, 1987. 471-585.

Bießenecker, Stefan, ed. “Und sie erkannten, dass sie nackt waren”: Nacktheit im Mittelalter. Bamberg: U of Bamberg P, 2008. Bamberger interdisziplinäre Mittelalterstudien 1.

Brander, Laura. "Nackte Verführung und enthaltsame Jungfrau: Funktion und Instrumentalisierung von Nacktheit im Umfeld von Brautwerbung, Beilager und Hochzeitsnacht." "Und sie erkannten, dass sie nackt waren": Nacktheit im Mittelalter. Ed. Stefan Bießenecker. Bamberg: U of Bamberg P, 2008. 289-320. Bamberger interdisziplinäre Mittelalterstudien 1.

Bynum, Caroline W. "The Body of Christ in the Later Middle Ages: A Reply to Leo Steinberg.” Renaissance Quarterly 39.3 (1986): 399-439.

Classen, Albrecht, ed. Sexuality in the Middle Ages and Early Modern Times: New Approaches to a Fundamental Cultural-Historical and Literary-Anthropological Theme. Berlin, New York: Gruyter, 2008. Fundamentals of Medieval and Early Modern Culture 3.

-. "Naked Men in Medieval German Literature and Art: Anthropological, Cultural-Historical, and Mental-Historical Investigations." Sexuality in the Middle Ages and Early Modern Times: New Approaches to a Fundamental Cultural-Historical and Literary-Anthropological Theme. Ed. Albrecht Classen. Berlin, New York: Gruyter, 2008. 143-69. Fundamentals of Medieval and Early Modern Culture 3.

Denny-Brown, Andrea. Fashioning Change: The Trope of Clothing in High- and LateMedieval England. Columbus, OH: Ohio State UP, 2012.

Duerr, Hans P. Nacktheit und Scham. Frankfurt a. M.: Suhrkamp, 1988. Der Mythos vom Zivilisationsprozess Bd. 1.

Elias, Norbert. Über den Prozess der Zivilisation. Basel: Haus zum Falken, 1939.

Hahn, Thomas, ed. The Avowyng of Arthur. Sir Gawain: Eleven Romances and Tales. Kalamazoo, MI: Medieval Institute Publications, 1995. 113-68.

- Sir Gawain and the Carle of Carlisle. Sir Gawain: Eleven Romances and Tales. Kalamazoo, MI: Medieval Institute Publications, 1995. 81-112. 
Hinz, Michael. Der Zivilisationsprozess: Mythos oder Realität? Wissenschaftssoziologische Untersuchungen zur Elias-Duerr-Kontroverse. Opladen: Leske + Budrich, 2002. Figurationen 4.

Hopkins, Amanda. "Wordy vnthur wede': Clothing, Nakedness and the Erotic in some Romances of Medieval Britain." The Erotic in the Literature of Medieval Britain. Ed. Amanda Hopkins and Cory Rushton. Cambridge, NY: Brewer, 2007. 53-81.

Jütte, Robert. "Der anstößige Körper: Anmerkungen zu einer Semiotik der Nacktheit." Gepeinigt, begehrt, vergessen: Symbolik und Sozialbezug des Körpers im späten Mittelalter und in der frühen Neuzeit. Ed. Klaus Schreiner and Norbert Schnitzler. München: Fink, 1992. 109-29.

Kelly, Molly R. "Sex and Fertility in Marie de France's Lais." Sexuality in the Middle Ages and Early Modern Times: New Approaches to a Fundamental Cultural-Historical and Literary-Anthropological Theme. Ed. Albrecht Classen. Berlin, New York: Gruyter, 2008. 241-56. Fundamentals of Medieval and Early Modern Culture 3.

Kibler, William W., trans. The Knight with the Lion (Yvain). Chrétien de Troyes: Arthurian Romances. London: Penguin, 1991. 295-380.

Rahner, Johanna. "Ein nackter Gott? Theologische Perspektiven zur Nacktheit im Mittelalter." "Und sie erkannten, dass sie nackt waren": Nacktheit im Mittelalter. Ed. Stefan Bießenecker. Bamberg: U of Bamberg P, 2008. 173-84. Bamberger interdisziplinäre Mittelalterstudien 1.

Rouse, Robert A. “'Some Like it Hot': The Medieval Eroticism of Heat.” The Erotic in the Literature of Medieval Britain. Ed. Amanda Hopkins and Cory Rushton. Cambridge, NY: Brewer, 2007. 71-81.

Saunders, Corinne. "Subtle Crafts: Magic and Exploitation in Medieval English." The Exploitations of Medieval Romance. Ed. Laura Ashe, Ivana Djordjević, and Judith E. Weiss. Cambridge, N.Y: Brewer, 2010. 108-24. Studies in Medieval Romance 12.

Schultz, James A. "Bodies that Don't Matter: Heterosexuality before Heterosexuality in Gottfried's Tristan.” Constructing medieval sexuality. Ed. Karma Lochrie, Peggy McCracken, and James A. Schultz. Minneapolis: U of Minnesota P, 1997. 91-110. Medieval Cultures 11.

Shepherd, Stephen H. A., ed. Havelok. Middle English Romances: Authoritative Texts, Sources and Backgrounds, Criticism. A Norton Critical Edition. New York: Norton, 1995. 3-74.

- Sir Launfal. Middle English Romances: Authoritative Texts, Sources and Backgrounds, Criticism. A Norton Critical Edition. New York: Norton, 1995. 190-218.

- Sir Orfeo. Middle English Romances: Authoritative Texts, Sources and Backgrounds, Criticism. A Norton Critical Edition. New York: Norton, 1995. 174-90.

- Ywain and Gawain. Middle English Romances: Authoritative Texts, Sources and Backgrounds, Criticism. A Norton Critical Edition. New York: Norton, 1995. 75-173. 
Smith, Nicole D. Sartorial Strategies: Outfitting Aristocrats and Fashioning Conduct in Late Medieval Literature. Notre Dame, IN: Uof Notre Dame P, 2012.

Spearing, Anthony C. "Marie de France and her Middle English Adapters." Studies in the Age of Chaucer 12 (1990): 117-56.

Steinberg, Leo. The Sexuality of Christ in Renaissance Art and in Modern Oblivion. New York: Pantheon Books, 1983.

Winst, Silke. "Körper und Identität: Geschlechtsspezifische Codierung von Nacktheit im höfischen Roman um 1200." "Und sie erkannten, dass sie nackt waren": Nacktheit im Mittelalter. Ed. Stefan Bießenecker. Bamberg: U of Bamberg P, 2008. 337-54. Bamberger interdisziplinäre Mittelalterstudien 1. 